Замазій А. А., доктор ветеринарних наук

Полтавська державна аграрна академія

\title{
ВЗАСМОЗВ'ЯЗОК СКЛАДУ АМНІОТИЧНОЇ РІДИНИ ТА «ЗРІЛОСТІ» СУРФАКТАНТНОЇ СИСТЕМИ ЛЕГЕНЬ У НОВОНАРОДЖЕНИХ КЛІНІЧНО ЗДОРОВИХ ТЕЛЯТ
}

\section{Рецензент - доктор ветеринарних наук В. О. Свстаф'єва}

\begin{abstract}
Наведено дані про амінокислотний склад $і$ взаємозв'язок амніотичної рідини та «зрілості» сурфактантної системи легень у новонароджених клінічно здорових телят. Встановлено, щзо «зрілість» сурфактантної системи легень була виявлена у 40,0\% телят від корів-первісток. Вона була менша у 1,80-1,70 рази $(p<0,01)$ у телят, отриманих від корів другоготретього отелення. Сумарна фракція фосфоліпідів амніотичної рідини була в 1,38 разу більшою, ніж у тварин, народжених у стані гіпоксї $(p<0,01)$. Загальний вміст амінокислот у навколоплідній рідині клінічно здорових новонароджених телят становив

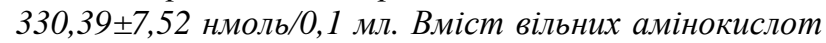
знаходиться на рівіні 222,97士3,82 нмоль/0,1 мл. Із них на частку незамінних амінокислот припадало

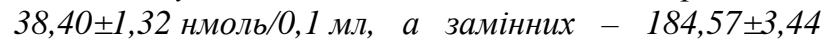
нмоль/0,1 мл.
\end{abstract}

Ключові слова: плід, амінокислотнищй склад, амніотична рідина.

Постановка проблеми. Підтримання гравідарного гомеостазу в організмі вагітних забезпечується матір'ю, плацентою і плодом. Порушення в одній із ланок викликає компенсаторні реакції в іншій, що направлені на виношування й народження здорового приплоду.

3 огляду на це, важливого значення набувають питання щодо знань зрілості сурфактантної системи та складу амніотичної рідини за умов фізіологічної течії вагітності тварин [1, 3, 8, 9].

Більшість дослідників вказує, що тільки 7$15 \%$ новонароджених тварин здатні адаптуватися до нових умов існування після народження. Решта ж тварин народжується 3 певною мірою внутрішньоутробної недорозвиненості, передусім системи дихання та імунокомпетентних структур і органів [3-5, 8]. Характерною особливістю зниження життєздатності неонатальних продуктивних тварин $є$ їх $100 \%$ захворювання в перші дні життя, а перехворілі тварини відстають у рості й розвитку.

Тому для вирішення проблеми необхідно насамперед на глибокій науковій основі формувати ветеринарну неонатологію, проблеми якої пов' язані з вирішенням задач щодо отримання та вирощування здорових високопродуктивних тварин $[1,7,9]$.

Проведені дослідження були складовою частиною тематичного плану «Розробка мультипараметричної системи виробництва молока на основі секретоутворюючої функції молочної залози, пре- та постнатального розвитку тваринного організму і методів їх корекції» номер державної реєстрації 0108U010281 (Розділ 2. «Фізіолого-біохімічні параметри пре- та постнатального розвитку тварин та їх корекція».

Аналіз основних досліджень і публікацій, в яких започатковано розв'язання проблеми. Будь-яка система утримання й вирощування телят [3] не може забезпечити отримання здорових тварин із високою продуктивністю, якщо вона не враховує особливості росту й розвитку плоду та новонароджених тварин $[2,7,9]$.

Одним 3 основних завдань у цілях розробки заходів, спрямованих на підвищення адаптативних здатностей організму, $\epsilon$ знання фізіологічних основ росту і розвитку організму у пре- та постнатальні періоди життєдіяльності $[2,7]$. Критичні періоди життєдіяльності організму спостерігаються в основному на ранніх стадіях пре- та постнатального росту і розвитку.

Відомо, що порушення матково-плацентарноплодової гемодинаміки у ранні строки вагітності $€$ причиною первинної плацентарної недостатності, ускладнень вагітності й розвитку гіпоксії плода.

За результатами досліджень, у системі гомеостазу у корів сухостійного періоду відбуваються істотні зміни, що $є$ елементами фізіологічної адаптації $[4,5]$.

У зв' язку з цим значної уваги необхідно надавати дослідженню складу амніотичної рідини, що вказує на «зрілість» сурфактантної системи легень у новонароджених тварин, оскільки знання та аналіз причин, які їх викликають, сприяють розробці способів і прийомів отримання життєздатного приплоду, підвищення відтворної функції корів. 


\section{ВЕТЕРИНАРНА МЕДИЦИНА}

Мета досліджень - «зрілість» сурфактантної системи легень у новонароджених телят та амінокислотний склад амніотичної рідини за умов фізіологічної течії тільності у корів.

Завдання - встановити «зрілість» сурфактантної системи легень та зміни в амінокислотному складі амніотичної рідини за умов фізіологічної течії тільності у корів.

Матеріали та методи досліджень. Лабораторні дослідження проведено в умовах кафедри патологічної анатомії та патофізіології ПДАА, анатомії, нормальної та патологічної фізіології тварин СНАУ, відділу № 20 Інституту прикладної фізики НАН України (м. Суми).

Зрілість сурфактантної системи легень у новонароджених телят визначали за «пінним тестом» і тестом «одного видиху», запропонованого нами.

На амінокислотному аналізаторі BIOTRONIK LC-6001 (Німеччина) 3 інтегратором SP-4100 на основі післяколонкової реакції 3 нінгідрином проводили дослідження амінокислотного складу рідин гомеостатичного рівня організації функціональноактивних новонароджених телят.

Результати досліджень. Результати проведених нами досліджень свідчать, що за «пінним тестом» «зрілість» сурфактантної системи легень виявлена у $29,77 \%$ новонароджених телят.

Наведені у таблиці 1 результати досліджень доводять, що «зрілість» сурфактантної системи легень за вищезазначеним тестом була виявлена у 40,0 \% телят від корів-первісток.

Цей показник був меншим у $1,80-1,70$ разів ( $<<0,01)$ у телят, отриманих від корів другоготретього отелення, а від корів четвертого отелення була незначно нижчою у порівнянні 3 попереднім показником.

За запропонованим нами тестом «одного ви- диху» позитивний результат «зрілості» сурфактантної системи легень виявлено у 43,63\% новонароджених телят.

За даними обох тестів «зрілість» сурфактантної системи легень була найнижчою в телят, які народилися від корів-первісток (у середньому становила $45 \%$ ). За показниками двох тестів близько $36,70 \%$ телят народжується 3 «незрілою» сурфактантною системою легень, 19,05\% - у стані гіпоксії (в 1,92 більше, $\mathrm{p}<0,01$ ).

У відібраних зразках навколоплідної рідини нами проведено визначення сумарної фракції фосфоліпідів.

Отримані нами результати досліджень амніотичної рідини 3 визначення вмісту сумарної фракції фосфоліпідів практично співпадають із даними, одержаними нами в ході визначення «зрілості» сурфактантної системи легень новонароджених телят без визначення сумарної фракції фосфоліпідів.

Відповідність результатів визначення «зрілості» ССЛ за двома тестами становила 85,71 \%, що свідчить про більш високу чутливість і специфічність запропонованого нами тесту.

Побічно про «зрілість» сурфактантної системи легень свідчать також показники вмісту основних класів жирів ліпідної фракції навколоплідної рідини (табл. 2), що використовуються у синтезі сурфактанту.

У навколоплідній рідині телят, які народилися клінічно здоровими, вміст фосфорилхоліну становив $707,00 \pm 5,00$ а. о. м, що в 1,20 разу більше від даного показника навколоплідної рідини плодів, які народилися у стані гіпоксії ( $<<0,05)$.

Сумарна фракція фосфоліпідів амніотичної рідини (новонароджені клінічно здорові телята) була в 1,38 разу більшою, ніж у тварин, народжених в стані гіпоксії ( $\mathrm{p}<0,01)$.

\section{1. «Зрілість» сурфактантної системи легень новонароджених телят за «пінним тестом»}

$\boldsymbol{i}$ «тестом одного видиху» (\%)

\begin{tabular}{|c|c|c|c|c|c|c|c|c|}
\hline \multirow{4}{*}{ Групи корів } & \multicolumn{8}{|c|}{$\begin{array}{c}\text { «Зрілість» сурфактантноі системи } \\
\text { легень телят за: }\end{array}$} \\
\hline & \multicolumn{4}{|c|}{ «пінним тестом» } & \multicolumn{4}{|c|}{ «тестом одного видиху» } \\
\hline & \multicolumn{2}{|c|}{ негативний } & \multicolumn{2}{|c|}{ позитивний } & \multicolumn{2}{|c|}{ негативний } & \multicolumn{2}{|c|}{ позитивний } \\
\hline & $\mathrm{n}$ & $\%$ & $\mathrm{n}$ & $\%$ & $\mathrm{n}$ & $\%$ & $\mathrm{n}$ & $\%$ \\
\hline Першого отелення $(n=10)$ & 6 & 60,00 & 4 & 40,00 & 5 & 50,00 & 5 & 50,00 \\
\hline Другого отелення $(\mathrm{n}=18)$ & 14 & 77,78 & 4 & $22,22^{\bullet}$ & 11 & 61,11 & 7 & 38,89 \\
\hline Третього отелення (n=17) & 13 & 76,47 & 4 & $23,53^{-}$ & 10 & 58,82 & 7 & 41,18 \\
\hline Четвертого отелення $(\mathrm{n}=18)$ & 12 & 66,67 & 6 & 33,33 & 10 & 55,56 & 8 & 44,44 \\
\hline У цілому & 45 & 70,23 & 18 & $29,77^{\bullet}$ & 36 & 56,37 & 27 & 43,63 \\
\hline
\end{tabular}

Примітка: "p<0,01 у порівняні між «пінним тестом» $\mathrm{i}$ «тестом одного видиху» 
ВЕТЕРИНАРНА МЕДИЦИНА

\section{2. Класи жерів ліпідної фракції навколоплідної рідини новонароджених клінічно здорових та у стані гіпоксї телят (М土m, а. о. м)}

\begin{tabular}{|c|c|c|}
\hline Показник & Клінічно здорові телята $(\mathrm{n}=3)$ & $\begin{array}{c}\text { Телята у стані гіпоксії } \\
(\mathrm{n}=7)\end{array}$ \\
\hline Фосфорилхолін & $707,00 \pm 5,00$ & $588,00 \pm 3,00^{\square}$ \\
\hline Вільний холестерол & $677,00 \pm 4,00$ & $517,14 \pm 4,02^{\bullet}$ \\
\hline Сумарна фракція фосфоліпідів: & $654,92 \pm 3,57$ & $473,07 \pm 3,06$ \\
- фосфатидилетаноламін & $78,33 \pm 3,11$ & $62,68 \pm 2,88^{\square}$ \\
\hline - фосфатидилсерин & $141,67 \pm 3,54$ & $92,14 \pm 2,96^{\square}$ \\
\hline - фосфатидилхолін & $183,33 \pm 4,21$ & $121,43 \pm 3,52^{\bullet}$ \\
\hline - лізолецитин & $159,00 \pm 4,00$ & $92,14 \pm 2,92^{\square}$ \\
\hline - сфінгмомієлін & $92,59 \pm 3,00$ & $104,68 \pm 3,03$ \\
\hline Співвідношення С/Л & $1,98: 1$ & $1,16: 1$ \\
\hline Тригліцериди & $165,00 \pm 2,00$ & $100,00 \pm 2,00^{\bullet}$ \\
\hline
\end{tabular}

Примітка: ${ }^{\square}$ < 0,05; "p<0,01 у порівняні з групою клінічно здорових телят

Необхідно зазначити, що частка фосфатидилетаноламіну в амніотичній рідині клінічно здорових телят становила $11,08 \%$, а у телят, які народилися у стані гіпоксії, $-14,00 \%$.

Водночас, уміст фосфатидилетаноламіну в навколоплідній рідині клінічно здорових телят був вищим у 1,25 разу $(\mathrm{p}<0,05)$, аніж в амніотичній рідині телят, які народилися у стані гіпоксії.

Частка фосфатидилсерину в навколоплідній рідині новонароджених клінічно здорових телят i телят у стані гіпоксії коливалася в межах від 20,04 до 20,61 \% від загальної суми ліпідів, однак вміст фосфатидилсерину $(141,67 \pm 3,54 \ldots$ $92,14 \pm 2,96$ а.о.м.) був більшим у 1,54 разу в навколоплідній рідині клінічно здорових телят $(\mathrm{p}<0,01)$.

Вміст фосфатидилхоліну (лецитину) в амніотичній рідині телят, які народилися клінічно здоровими, був в 1,51 разу ( $<0,01)$ більшим, аніж у навколоплідній рідині телят, які народилися у стані гіпоксії.

Лізолецитину та сфінгмомієліну виявлено у навколоплідній рідині новонароджених клінічно здорових телят у $1,14(\mathrm{p}<0,05)-1,83$ рази більше ( $<<0,01)$, ніж у амніотичній рідині телят, які народилися у стані гіпоксії.

Разом із тим, необхідно вказати, що відсоток лізолецитину у сумарній фракції ліпідів амніотичної рідини телят дослідної групи становив $19,48 \%$, а сфінгмомієліну - 22,13\%.

У навколоплідній рідині клінічно здорових телят ці показники були відповідно вищими на
24,28 та $14,14 \%$. Співвідношення лецитину до сфінгмомієліну в амніотичній рідині клінічно здорових телят становило $1,98: 1$, а у телят дослідної групи було на рівні $1,16: 1$.

У навколоплідній рідині телят, які народилися клінічно здоровими, вміст тригліцеридів був в 1,65 разу більшим, аніж у амніотичній рідині телят, які народилися у стані гіпоксії ( $<<0,01)$.

Результати наших досліджень свідчать, що загальний вміст амінокислот у навколоплідній рідині клінічно здорових новонароджених телят становив 330,39 $\pm 7,52$ нмоль/0,1 мл. Вміст вільних амінокислот (табл. 3) у амніотичній рідині клінічно здорових телят знаходився на рівні $222,97 \pm 3,82$ нмоль/0,1 мл; із них на частку незамінних амінокислот припадало $38,40 \pm 1,32$ нмоль/0,1 мл, а замінних - 184,57 $\pm 3,44$ нмоль/0,1 мл.

Аналіз амінокислотного складу навколоплідної рідини клінічно здорових новонароджених телят дав змогу встановити, що у ній значно більшим був вміст компонентів, які беруть участь в орнітиновому циклі.

Основною амінокислотою, що бере участь на початковому етапі даного циклу, $\epsilon$ орнітин. Ïї вміст у амніотичній рідині клінічно здорових новонароджених телят становив $3,43 \pm 0,04$ нмоль/0,1 мл, а у телят, які народилися у стані різного рівня гіпоксії, цей показник був у 10,09, $3,30(\mathrm{p}<0,001)$ та 1,26 рази меншим $(\mathrm{p}<0,05)$. Цитруліну у навколоплідній рідині клінічно здорових телят виявлено на рівні $3,91 \pm 0,25$ нмоль/0,1 мл. 
ВЕТЕРИНАРНА МЕДИЦИНА

3. Загальні показники амінокислотного складу навколоплідної рідини новонароджсених клінічно здорових телят (М $\pm m$, нмоль/0,1 мл, $n=5)$

\begin{tabular}{|c|c|}
\hline Показник & Клінічно здорові телята \\
\hline Усього & $330,39 \pm 7,52$ \\
\hline Вільні амінокислоти & $222,97 \pm 3,82$ \\
\hline Незамінні амінокислоти & $38,40 \pm 1,32$ \\
\hline Замінні амінокислоти & $184,57 \pm 3,44$ \\
\hline Вміст глюкопластичних амінокислот & $39,32 \pm 0,32$ \\
\hline Вміст ліпопластичних амінокислот & $20,01 \pm 1,24$ \\
\hline
\end{tabular}

У перспективі дослідження 3 даного напряму дозволять встановити фізіологічні параметри росту й розвитку плода, сприятимуть розробці способів і прийомів отримання життєздатного приплоду, підвищення відтворної функції корів.

Висновки: 1. Результати досліджень свідчать про взаємозв'язок складу амніотичної рідини плода корів та «зрілості» сурфактантної системи легень новонароджених телят.

1. За «пінним тестом» «зрілість» сурфактантної системи легень виявлена у $29,77 \%$, а за запропонованим нами тестом «одного видиху»у 43,63\% новонароджених телят.

2. Доведено, що співвідношення лецитину до сфінгмомієліну в амніотичній рідині клінічно здорових телят становило $1,98: 1$, а у телят, які

\section{БІБЛІОГРАФІЯ}

1. Гаврилін П. М. Концепція підвищення життєздатності новонароджених телят / П. М. Гаврилін, Б. В. Криштофорова, Д. М. Масюк [та ін.] // Вісник Дніпропетровського ДАУ. - 2004. №1. - С. 96-98.

2. Замазій A. А. Трансформація депонованої енергії на продукцію у корів і її вплив на зрілість сурфактантно-альвеолярної системи новонароджених телят / М. Д. Камбур, А. А. Замазій // Вісник Сумського НАУ. - 2006. - № 1-2. C. 61-63.

3. Замазій А. А. Влияние биоэлементов на метаболическую адаптацию новорожденных телят / А. А. Замазій, М. Д. Камбур, В. М. Клемазов // Материалы $\mathrm{X}$ Международной научно-произ. конф. «Проблемы сельскохозяйственого производства на современном этапе и пути их решения», Россия, Белгород, 15-19 мая 2006 г. - Т. 2. - C. 121.

4. Замазій А. А. Жирнокислотний склад крові та навколоплідних рідини функціонально активних новонароджених телят / А. А. Замазій // Науково-технічний бюлетень Інституту біології тварин - Львів, 2008. - Вип. 9, №3. - С. 48-52. народилися у стані гіпоксії, 1,16: 1 .

3. Загальний вміст амінокислот у навколоплідній рідині клінічно здорових новонароджених телят становив 330,39 $\pm 7,52$ нмоль/0,1 мл,

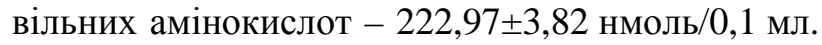
Iз них на частку незамінних амінокислот припадало $38,40 \pm 1,32$ нмоль $/ 0,1$ мл, а замінних $184,57 \pm 3,44$ нмоль/0,1 мл.

4. У навколоплідній рідині клінічно здорових новонароджених телят високим виявся вміст компонентів, які беруть участь в орнітиновому циклі.

5. Вміст орнітину в амніотичній рідині клінічно здорових новонароджених телят становив $3,43 \pm 0,04$ нмоль/0,1 мл, а цитруліну - 3,91 $\pm 0,25$ нмоль/0,1 мл.

5. Замазій А. А. Лікування гіпоксії новонароджених телят / А. А. Замазій // Науковий вісник Львівського національного університету ветеринарної медицини та біотехнології ім. С. З. Гжицького. - Львів, 2009. - Т. 11, №2 (41). - Ч. 1. C. 76-79.

6. Замазій А. А. Корекція гіпоксії новонароджених телят / А. А. Замазій // Вісник Сумського НАУ. - 2009. - №2 (23). - С. 29-33.

7. Камбур М. Д. Вплив енергетичного забезпечення організму корів на секреторну функцію молочної залози і життєздатність приплоду / М. Д. Камбур, А. А. Замазій // Науково-технічний бюлетень Інституту біології тварин, ДНДКІ ветпрепаратів та кормових добавок. - Львів, 2009. - Вип. 10. - № 1-2. - С. 45-50

8. Криштофорова Б. В. Біологічні основи ветеринарної неонатології / Б.В.Криштофорова, В. В. Лемещенко, Ж. Г. Стегней. - Сімферополь: Терра Таврика, 2007. - 368 с.

9. Яблонський B. A. Проблеми відтворення тварин на рубежі XXI століття / В. А. Яблонський // Науковий вісник Національного аграрного університету. - К., 2000. - №22. - С. 16-21. 